\title{
官能検査システム化研究会の活動と展望
}

\section{Activities of Sensory Evaluation Systematization WG and Prospect of Related Technologies}

\author{
官能検査システム化研究会
}

\section{1.はじめに}

官能検査システム化研究会は, 半導体・エレクトロニク ス分野をはじめとする種々の生産現場で実施されている目 視検査を中心に，それを自動化・システム化する技術につ いて，最新技術の発信，情報交換，および人材交流などを 目的として活動している。現在, 産学官から 22 名の皆様に 委員として参加いただいている。本年度は活動開始から第 2 期（1 期は 2 年）を迎え, 研究会の名称を昨年度までの官 能検査自動化研究会から現名称に変更している。自動化か らシステム化に変更したのは, 個別の自動化技術にとどま らず，生産システムとして大きく捉えるべきとの当研究会 委員会での議論の結果である。

本年度も産業界ではさまざまなニュースがあった。中で もクラウドやモバイルというビジネス環境で発展を続けて いるインターネットについては, 次の大きなムーブメント として IoT (Internet of Things) の登場に注目が集まってい る。IoT は, インダストリー4.0のインパクトとともにもの づくりの世界にも新たな潮流を生み出しており, 今後の産 業・社会に大きな変革を生み出すことが期待されている。 一方で，さまざまな分野において製品の品質・信頼性をめ ぐる問題は増加傾向にあり, 深刻化している感がある。そ のため, 品質・信頼性を支える評価技術・検査技術につい ては, ますます重要性が増しているが, 人が直接検査に関 わる官能検査については, 現状のままでは次代の潮流に合 致しないのは明らかである。

本稿では，本研究会での議論を通じて官能検査自動化・ システム化に関する検査技術の現状と課題を整理し, 今後 の展望を述べる。

\section{2. 公開研究会の概要}

競争力のあるものづくりを目指して, 高速化, 可視化, 定量化, および共通化などをテーマに掲げて, 官能検査自 動化・システム化に関する最新技術, 企業の有する製品技 術など，この分野では共通性の高い取り組みのご発表をい
ただいた。直近の 2 回の公開研究会の概要について紹介し たい。

\section{1) 第 4 回公開研究会（平成 27 年 1 月 28 日開催）}

最初に経営支援 NPO クラブの長谷川堅一氏 ${ }^{1)}$ から「今 こそ競合に勝てる PCB 作りを実践せよ」と題して基調講演 をいただいた。日本は開発を担当, アジアで量産といった 電子回路業界の傾向から脱皮して，本来の製品価格競合に も勝てる業界に戻す必要性とともに，そのための具体策の 提言があった。虚報無し AOI 検査で確認工程を無用にする ことの重要性などが紹介された。

伊藤忠テクノソリューションズの鈴置昌宏氏 ${ }^{2)}$ から高速 度カメラを用いた画像処理とその応用として，ラインおよ びエリアスキャンキャンカメラの最新技術動向について, 富士テクニカルリサーチの渡邊 惊氏 ${ }^{3)}$ から光切断法の原 理を用いて基板の寸法や，傾き・たわみなど，3 次元外観 形状を短時間かつ高解像度で測定できる検査システムにつ いて，それぞれ製品技術紹介をいただいた。

産総研の菊永和也氏 ${ }^{4)}$ からは, 静電気可視化計測技術と して，带電している対象物を直接または間接的に励振させ ることで時間変化する電界を誘起し，その変化を遠隔で検 出する静電気計測技術が紹介された。また, 筆者からは, プリント配線板のめつきムラの検査技術について紹介させ ていただいた。光沢ムラおよび色ムラを散乱光の偏光成分 および波長依存の比でそれぞれ捉え, 特徵量抽出と多変量 解析の組み合わせで, 最終的には数值化して評価できるこ と, 並行して, 現在, IEC/TC91 WG10でめっき外観のあ たらしい試験方法として標準化の提案を実施していること などを報告させていただいた ${ }^{5)}$ 。

\section{2) 第 5 回公開研究会 (平成 27 年 7 月 28 日開催)}

進化する画像センシングをテーマとして，最初に，中京 大の輿水大和氏 ${ }^{6)}$ から「画像技術の元気の素」と題して特 別講演をいただいた。画像技術には長い歴史があり，最近 はさまざまな現場で非常な活況を呈しているが，その本性 は極まっておらず，例えば，画像デジタル化の理論的根 拠，エッジ検出の基本原理の枯渇，周辺視や大局視覚の技 
術不足, 感性センシングの要請など, 画像技術の俯瞰と共 に，最新の技術についても解説いただいた。

昭和電気研究所の大島玩也氏 ${ }^{7)}$ からは, 光学技術と画像 処理技術の融合による“見えない”を“見える”にしてか らの画像処理の具体例として, ACF 検査装置およびウェハ クラック・チッピング検査装置などをご紹介いただいた。

産総研の重森清史氏 ${ }^{8)}$ からは, スギの葉形状による品種 分類について，林業における官能検查の事例紹介をいただ いた。また, 同所の寺崎 正氏 ${ }^{9)}$ からは, 年間 1 兆個のセ ンサを使用し，無意識の内に損失の無い「潤沢な社会」を 実現するトリリオンセンシングの概念と共に, クラック， ひずみなどを可視化するセンシング，超低価格・低環境負 荷センサの開発について紹介された。

\section{3. 官能検査の現状と課題}

官能検査自動化を人間の目と頭脳に置き換えて考えてみ る。

目の部分については，上記でも紹介されたように最近の カメラ技術の進展がめざましい。秒速 1,000 コマ以上で動 作する高速ビジョン技術も実用化されており, 昆虫や鳥の 羽ばたく様子も静止画で捕らえられる。見えないものを診 る技術として産業のさまざまな分野への応用が期待でき る。これからの IoT 時代には, ものづくりの現場ではすべ ての情報をデー夕にする必要が高まってくることから，お そらく画像についても capture から measure への取り組みが 重要になってくるものと思われる。また, 基板など比較的 大きめの対象物についての 3 次元計測の技術もミクロン オーダーまで進んできており, さらなる高精度化が期待さ れている。

頭脳の部分については, 最近の PC の処理能力の向上に 伴って, 画像処理技術には相当の進展が認められる。ま た，最近では，チェスや将棋において人間とコンピュー夕 の対局としてトピックとなっているように，人工知能 (AI) の研究がすばらしい成果を上げている。AI の産業応用も今 後はますます進んでくるものと期待されている。

官能検査の自動化について，ハード，ソフトの両面から これまで相当の進展があったものの, トータルシステム化 としてみた場合，技術的にはまだ満足な域には達している とは言い難い。その最大の問題のひとつが, 多品種少量生 産への柔軟な対応に難があることだろう。これについて は，青木氏 ${ }^{10)}$ の報告が詳しい。外観検査では，おびただし い個別課題に対して一品一様でシステム開発することの困 難さが報告されている。

この辺の対応についてはまだまだ機械より人間が勝って いると言わざるを得ない。しかしながら, 微細化・高精度 化の進展と共に人の目ではそもそも対応困難な課題が増加 してきているのは周知の事実である。さらに, 熟練技術者 の不足, 海外での人件費高騰などのため, 自動化・システ
ム化の取り組みは必須の状況になっている。画像処理，外 観検查技術として，これまで相当の研究開発の歴史がある が，これらと新たな発想，あらたな技術のかけ算でブレイ クスルーが実現できるのではないかと考えている。そのひ とつの鍵は，人の持つ暗黙知は暗黙のままで処理する $\mathrm{AI} の$ 活用にあるのではないだろうか。また，検查技術の IoT 組み込みについては, やはり検查法の標準化も重要になっ てくるものと考えられる。新しい技術の開発と並行して共 通の物差しを持つ必要性も高まってくるはずである。

\section{4. おわりに}

本稿では, 本研究会の委員会㧍よび公開研究会などでの 議論を通じて, 官能検查自動化・システム化に関する検查 技術の現状と課題を整理し, 今後の展望について述べた。

日本のものづくりは, 高品質・高信頼性では世界最高レ ベルにある。一方で，この品質にこだわりすぎると過剩品 質になってしまうという問題を内包している。この辺が, 日本のものづくりの強みであり，また弱点でもあり得る。 客観評価の重要性が改めて認識される。このような議論 は，だいぶ以前から広く行われてきたものであるが，その 間に製造の方には第 4 次産業革命の波が押し寄せてきてい る。インターネットと AI の導入は製造にとっては必然で あるように思われる。ところで，品質・信頼性を現場で支 えている検查の現状については，どうであろうか。これま での製造技術の進渉と比較すれば決して満足のものとは言 えないだろう。

筆者は，これまでのナノテク，3D プリンタといった䪊 的な技術の展開を見ていると，日本の IoTでは，日本らし さをもっと前面に打ち出した IoTであって欲しいと考えて いる。それには，やはり世界最高レベルの品質と，信頼性 にこだわった， Internet of Trust としての取り組みが重要と 機会がある度に唱えている。これについては, 賛否含めて 種々ご意見があるものと思う。大いに議論していきたい。 次回の公開研究会は 1 月 27 日開催予定である。本研究会へ の皆様の積極的なご参加をお願いしたい。

文責・野中一洋/産業技術総合研究所 (2015.11.20- 受理)

\section{文献}

1）長谷川堅一：“今こそ競合に勝てる PCB 作りを実践せよ, ” 官能検查自動化研究会平成 26 年度第 4 回公開研究会, Vol. 2, No. 2, pp. 1-15, January 2015

2）鈴置昌宏：“高速度カメラを用いた画像处理とその応用〜ラ インおよびエリアスキャンカメラによる外観検査システ 厶 , , 官能検查自動化研究会平成 26 年度第 4 回公開研究 会, Vol. 2, No. 2, pp. 17-31, January 2015

3）渡邊 惊：“3 次元測定を用いた傾き，たわみ，寸法検查技 術,”官能検查自動化研究会平成 26 年度第 4 回公開研究会, 
Vol. 2, No. 2, pp. 33-43, January 2015

4) 菊永和也 : “静電気可視化計測技術, ”官能検查自動化研究 会平成 26 年度第 4 回公開研究会, Vol. 2, No. 2, pp. 45-53, January 2015

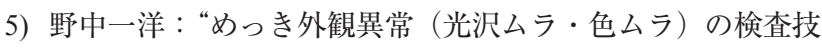
術と国際標準化, ”官能検査自動化研究会平成 26 年度第 4 回公開研究会, Vol. 2, No. 2, pp. 55-68, January 2015

6) 輿水大和：“画像技術の元気の素,”官能検査システム化研 究会平成 27 年度第 5 回公開研究会, Vol. 3, No. 1, pp. 1-9, July 2015

7) 大島挀也 : “光学技術と画像処理技術の融合, ”官能検査シ ステム化研究会平成 27 年度第 5 回公開研究会, Vol. 3, No. 1, pp. 11-28, July 2015

8) 重森清史 : “スギの葉形状による品種分類について一林業に おける官能検査の事例紹介, ”官能検査システム化研究会平 成 27 年度第 5 回公開研究会, Vol. 3, No. 1, pp. 29-46, July
2015

9）寺崎 正：“Trillion Sensors Universe を拓くセンシング,”官 能検査システム化研究会平成 27 年度第 5 回公開研究会,

Vol. 3, No. 1, pp. 47-53, July 2015

10）青木公也：“検査画像処理開発の道程,”官能検査自動化研 究会平成 25 年度第 1 回公開研究会, Vol. 1, No. 1, pp. 1-32, July 2013

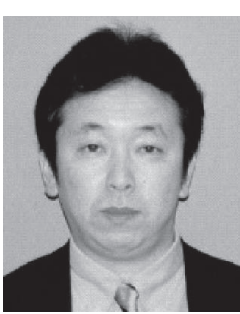

野中一洋（のなかかずひろ）

著者紹介 国立研究開発法人産業技術総合研究所 エレクトロニクス・製造領域研究戦略部 イノ ベーションコーディネータ 兼 製造技術研究部 門付

九州センター イノベーションコーディネータ 半導体・エレクトロニクス, 自動車, 化学・素材 など, 各種製造現場課題を中心に連携コーディ ネート, 研究開発, 試験方法の標準化などに従事。 